\title{
MONITORING PENERANGAN JALAN UMUM BERTENAGA SURYA MENGGUNAKAN KOMUNIKASI POWER LINE CARRIER COMMUNICATION
}

\author{
Britantyo Wicaksono ${ }^{1}$, Reza Istoni ${ }^{2}$ \\ ${ }^{I}$ Instrumentasi dan Kontrol Industri, Politeknik Negeri Jakarta, Jl. Prof. DR. G.A. Siwabessy, Kampus \\ Universitas Indonesia Depok 16425, Indonesia \\ ${ }^{2}$ Teknik Elektro, Universitas Dharma Persada, Jl. Taman Malaka Selatan - Pondok Kelapa - Jakarta \\ Timur 13450, Indonesia
}

Email: ${ }^{1}$ britantyo.wicaksono@elektro.pnj.ac.id, ${ }^{2}$ reza.istoni@mail.ru

\begin{abstract}
Solar Powered Street Lighting at Indonesia nowadays already has automation capability but not yet touch by industry 4.0 concept. However, there are lots of research regarding Street Lighting Monitor and control using IoT (Internet of Things) either it's Wireless or Wired. In this thesis, PLCC is used as a communication between Solar Powered Street Lighting through 1 phase electrical grid. This Solar Powered Street Light send those parameters that remote panel and solar panel have to control center. There are 15 parameter that monitored by control center plus 1 parameter for manual mode so that the street light can be controlled directly from control center. For this research purpose 2 solar powered street light was made and connected through PLCC for monitoring and control from control center. These street light then monitored for 24 hours, the purpose is to measure the electricity consumption of the LTMS (Long Term Monitoring System) that stick to the street light. The results are; the average of LTMS electricity consumption is 0,1 Watt, and the price comparison between PM + PdM and CBM of this LTMS shows that the BEP in year 6. Therefore, LTMS for solar powered street lighting is technically and economically feasible to be implemented at the industry
\end{abstract}

Keywords: Solar Powered Street Light, LTMS, PLCC, PM, CBM

\begin{abstract}
ABSTRAK
PJU bertenaga surya di Indonesia saat ini telah memiliki kemampuan otomasi tetapi masih belum tersentuh oleh konsep teknologi industry 4.0. sebenarnya sudah banyak riset tentang PJU bertenaga surya yang terkontrol dan termonitoring menggunakan IoT (Internet of Things) baik menggunakan kabel maupun nirkabel. Pada penelitian ini digunakan pendekatan metode komunikasi menggunakan PLCC melalui jaringan PLN 1 fasa. PJU bertenaga surya ini akan mengirimkan parameter-parameter pada panel remote dan solar panel serta terkontrol dari kontrol utama. Terdapat 15 parameter yang termonitor oleh kontrol utama. Dan 1 parameter untuk mode manual sehingga PJU dapat dikontrol langsung dari kontrol utama. PJU ini dimonitor selama 24 jam untuk mengukur pemakaian daya listrik dari LTMS (Long Term Monitoring System) PJU itu sendiri. Hasil dari penelitian ini adalah, pemakaian daya rata-rata LTMS untuk PJU bertenaga surya adalah 0,1 Watt, dan hasil perbandingan perhitungan PM + PdM dengan CBM PJU bertenaga surya adalah LTMS ini akan BEP pada tahun ke-6 sehingga LTMS PJU bertenaga surya secara teknis dan ekonomis layak untuk diimplementasikan pada dunia industri.
\end{abstract}

Keywords: PJU Bertenaga Surya, LTMS, PLCC, PM, CBM 


\section{Monitoring Penerangan Jalan Umum Bertenaga Surya .........}

\section{PENDAHULUAN}

Lampu jalan atau dikenal juga sebagai Penerangan Jalan Umum (PJU) adalah lampu yang digunakan untuk penerangan jalan dimalam hari sehingga mempermudah pejalan kaki, pesepeda dan pengendara kendaraan sehingga dapat melihat dengan lebih jelas jalan yang akan dilalui pada malam hari. Hal ini akan meningkatkan keselamatan lalu lintas dan keamanan dari para pengguna jalan dari kegiatan/aksi kriminal [1]. Clarke mengatakan bahwa penerangan (jalan) yang lebih baik akan menghalangi tindakan kriminal yang mengambil manfaat dari kegelapan malam [2].

PJU bertenaga surya telah diatur berdasarkan peraturan Menteri Perhubungan Republik Indonesia Nomor PM 27 Tahun 2018 dimana disebutkan bahwa, "Peralatan Hemat Energi adalah piranti atau perangkat atau fasilitas yang dalam pengoperasiannya memanfaatkan energi secara hemat sesuai benchmark hemat energi yang ditetapkan”. Karena itu, Dalam rangka meningkatkan penggunaan energi terbarukan, pemanfaatan energi matahari sebagai upaya penghematan energi listrik fosil pada lampu penerangan jalan sangat ditekankan oleh pemerintah [3].

Banyak PJU bertenaga surya yang terpasang saat ini telah sesuai dengan peraturan pemerintah, namun PJU itu belum termonitor dan terkontrol dari pusat kontrol, melainkan terkontrol dari masing-masing PJU ataupun kontrol perkelompok.

Berbagai metode dalam penelitian lain telah dilakukan untuk mengontrol dan memonitor PJU bertenaga surya seperti menggunakan komunikasi ethernet, IoT, Radio Frekuensi dan GPRS. Namun metode-metode tersebut tidak efisien dari sisi biaya, seperti ethernet yang memerlukan biaya pembelian kabel ethernet outdoor yang mahal dan IoT berbasis komunikasi 4G LTE dan GPRS yang sangat bergantung pada kuota internet, sedangkan metode komunikasi menggunakan radio frekuensi memiliki kelemahan pada besarnya daya yang dipakai dan terbatas pada jangkauan.

Pada penelitian kali ini dilakukan pendekatan metode lain, yaitu dengan menitikberatkan monitoring dan pengendalian menggunakan komunikasi PLCC (Power Line Carrier Communication) dengan Modbus ethernet sebagai protokolnya.

Tujuan penggunaan PLCC ini adalah untuk mengurangi pemasangan kabel monitoring dan penggunaan antenna yang memakan biaya dan memakan daya besar. Sehingga pengunaan jaringan listrik PLN yang ada sudah cukup untuk melakukan komunikasi antara PJU dengan LTMS.

\section{METODE PENELITIAN}

PLCC dengan protokol modbus TCP akan mengirimkan parameter-parameter terkait monitoring status PJU, seperti status baterai, tegangan baterai, tegangan solar cell, dll. Melalui protokol modbus TCP juga dapat mengontrol lampu dari ruang kontrol utama. Langkahlangkah penelitian dalam merealisasikan pembuatan prototipe ini dapat dilihat pada Gambar 1.

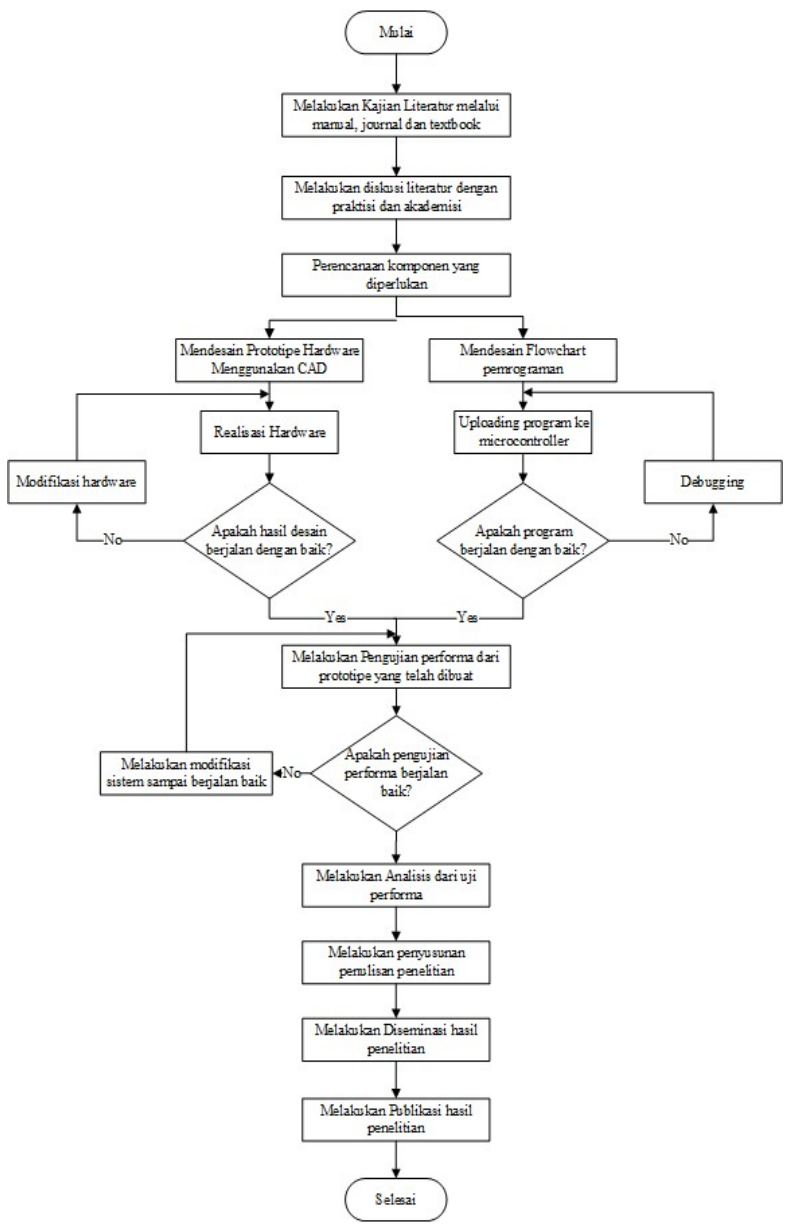

Gambar 1. Diagram alir metodologi penelitian

Pada tahap perencanaan komponen, yang dilakukan adalah membuat diagram blok dari prototipe sistem monitoring berbasis PLCC pada PJU bertenaga surya. Blok diagram sistem LTMS dapat dilihat pada Gambar 2. 


\section{Monitoring Penerangan Jalan Umum Bertenaga Surya .........}

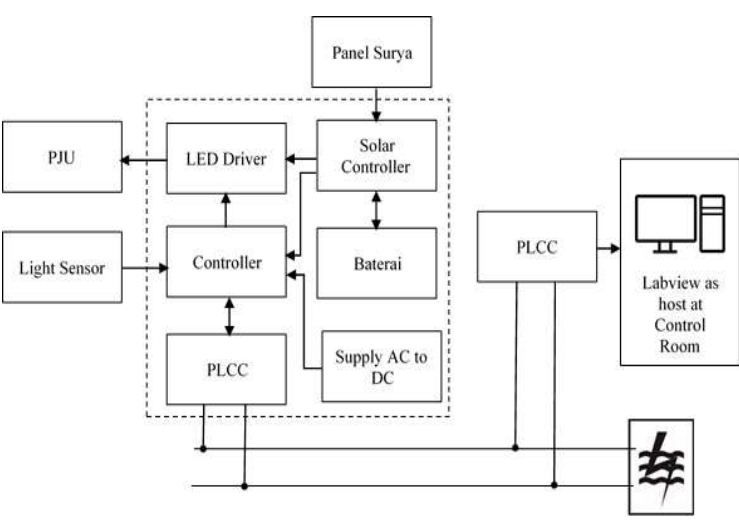

Gambar 2. Blok Diagram Sistem Monitoring

Blok diagram pada gambar 2 terdiri dari panel yang berisi solar controller, baterai, kontrol utama, modul PLCC, power supply PLN sebagai cadangan dan LED driver. Pada sistem ini terdapat program labVIEW pada PC sebagai interface antara sistem dengan manusia (operator) sekaligus bagian dari proses yang berhubungan langsung dengan akuisisi data. Prosesor akan mengolah data dari output plant yang selanjutnya ditampilkan pada monitor komputer.

Pada tahap desain prototipe hardware menggunakan CAD, dibuatlah wiring diagram dari sistem monitoring PJU bertenaga surya berbasis PLCC seperti Gambar 3.

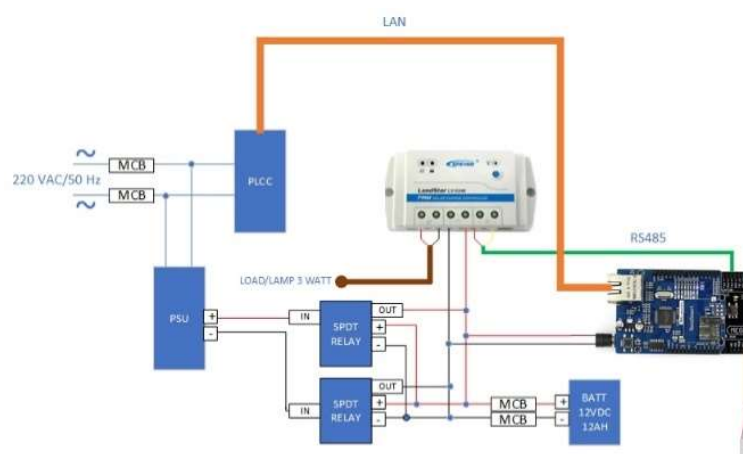

Gambar 3. Wiring diagram panel PJU

Pada tahap realisasi hardware, dibuatlah 2 prototipe PJU bertenaga surya dengan sistem monitoring berbasis komunikasi PLCC. Isi dari panel monitoring dari PJU tersebut dapat dilihat pada Gambar 4.

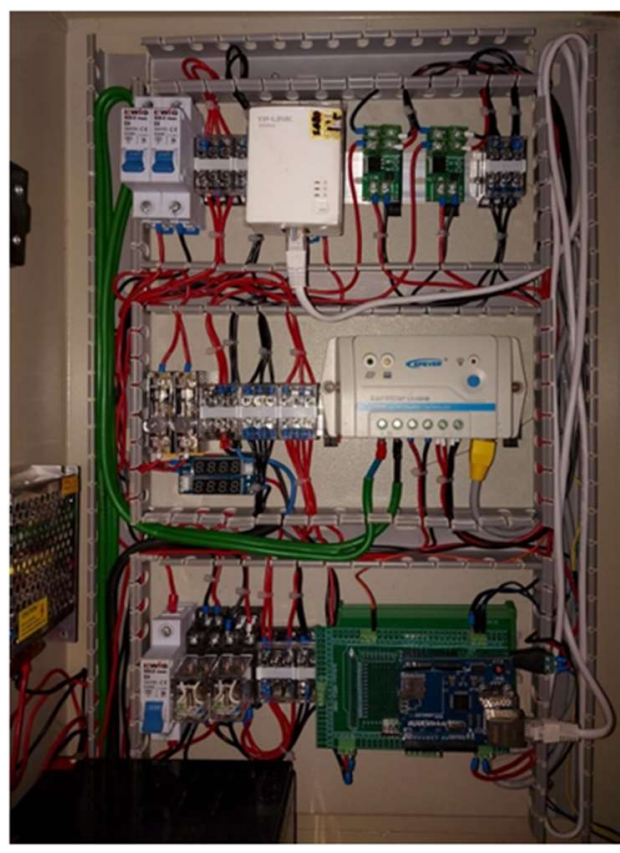

Gambar 4. Isi panel kontrol PJU

Pada gambar 4 diatas dapat dijelaskan bahwa jaringan PLN dipergunakan menjadi dua fungsi. Kegunaan pertama adalah jaringan 1 fasa yang masuk ke relay interlocking sebagai switch ke power dari PLN sehingga ketika baterai habis, daya otomatis akan beralih ke $12 \mathrm{~V}$ hasil keluaran power supply. Kegunaan kedua adalah sebagai pembawa sinyal PLCC dari PJU 1 dan 2 ke router.

Limit switch yang terkoneksi ke Arduino mendeteksi pintu terbuka. Data digital tersebut juga dikirim melalui ethernet lalu PLCC dan indikator tersebut dapat dilihat pada front end LabVIEW. LDR sensor yang terkoneksi ke analog output, berfungsi untuk mendeteksi intensitas cahaya matahari. Ketika siang hari dan kondisi Solar Charge Controller (SCC) dalam mode otomatis maka lampu akan mati, sedangkan pada malam hari lampu akan otomatis menyala.

SCC berfungsi sebagai solar controller, kegunaannya adalah untuk mengisi baterai, mendeteksi parameter-parameter pada baterai dan mengontrol lampu. Pengontrolan SCC dapat dilakukan melalui Modbus RTU melalui koneksi RS485 yang terkoneksi ke Arduino.

Pada tahap mendesain flowchart pemrograman, dibuatlah 2 flowchart pemrogaman, yaitu flowchart program Arduino yang berada di dalam panel control PJU dan flowchart program LabVIEW yang berfungsi sebagai LTMS. 


\section{Monitoring Penerangan Jalan Umum Bertenaga Surya .........}

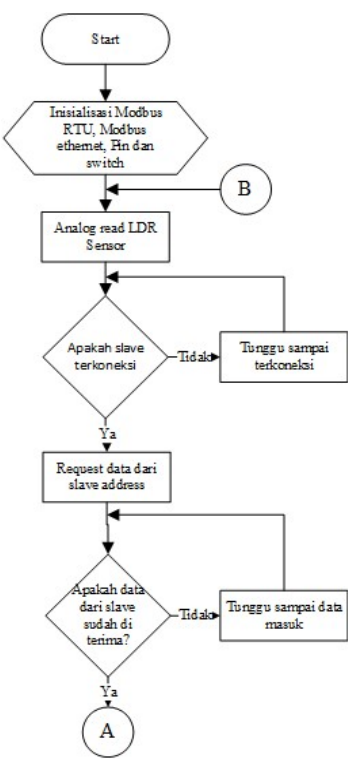

Gambar 5. Flowchart Pemrograman di Arduino

Dalam gambar 5 hal pertama yang dilakukan adalah menginisiasi fungsi-fungsi yang dipakai di dalam Arduino seperti Modbus RTU untuk koneksi, Pin Input Output Digital dan Analog, Modbus Ethernet. Berikutnya Arduino mengambil nilai intensitas cahaya menggunakan sensor LDR. Lalu Arduino mendeteksi apakah slave terkoneksi. Selama slave SCC tidak terkoneksi maka Arduino akan terus melakukan looping hingga slave terkoneksi. Setelah slave terkoneksi, Arduino akan me-request data dari slave SCC.

Flowchart pemrograman LabVIEW sebagai HMI pada control utama dan datalogger dapat dilihat pada Gambar 6.

Dalam flowchart Gambar 6, hal yang pertama kali dilakukan adalah menginisialisasi fungsi OPC (Open Platform Communication) dan konfigurasi IP address pengirim data yaitu Arduino melalui PLCC, bila IP Arduino benar maka OPC mengambil data dari Arduino menggunakan protocol Modbus TCP. Ketika data telah diterima, maka data tersebut akan dimasukkan kedalam variable array, lalu ditampilkan langsung di halaman front panel LabVIEW seperti Gambar 7 dan 8.

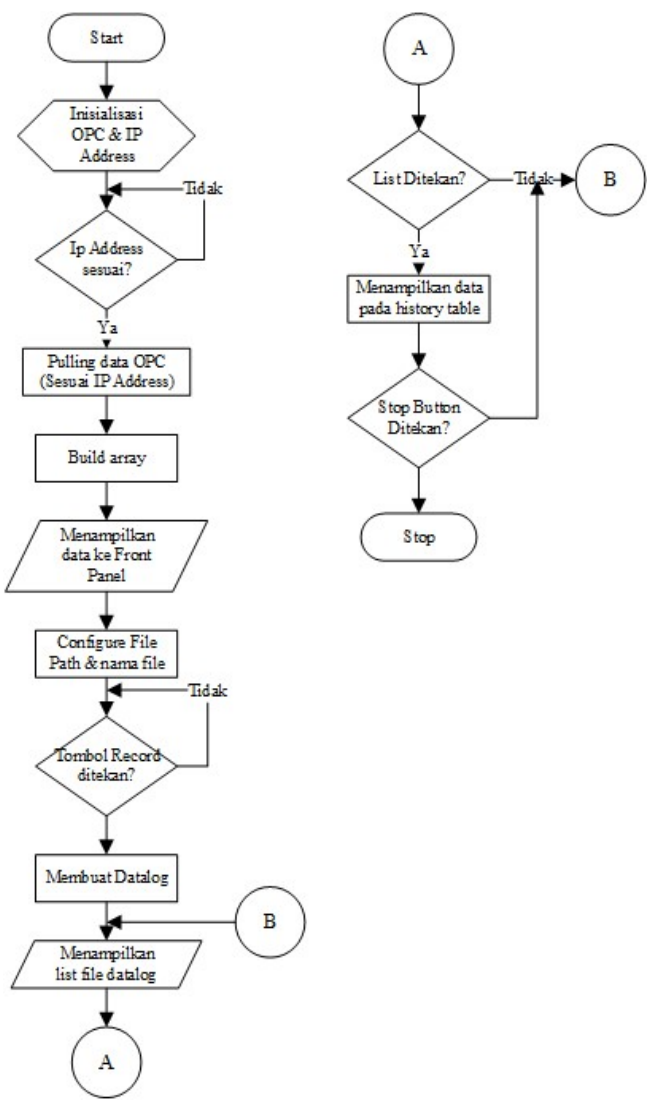

Gambar 6. Flowchart Pemrograman di LabView

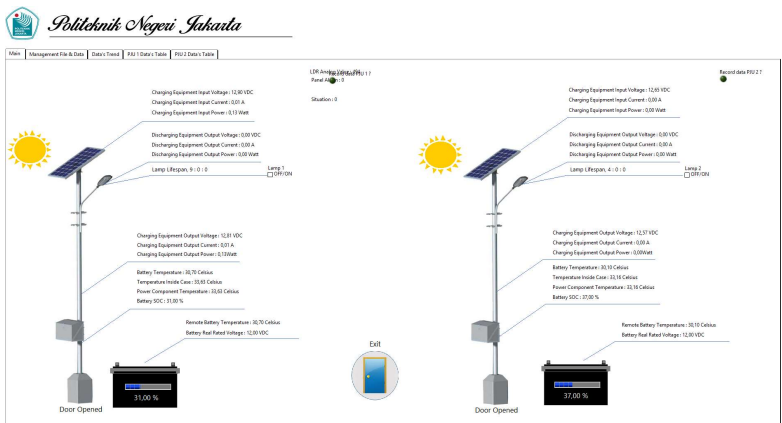

Gambar 7. Halaman utama front panel LabVIEW

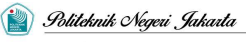

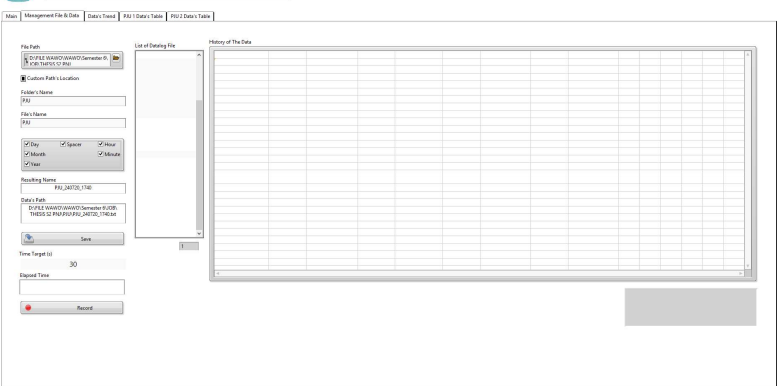

Gambar 8. Halaman kedua (manajemen file dan data) 
Gambar 8 adalah halaman kedua dari pemrograman LabVIEW yang memiliki dua kegunaan. Yang pertama adalah untuk menentukan folder dan file penyimpanan datalogger, yang kedua adalah untuk menentukan sampling time. Nama file datalogger akan dibuat berdasarkan konfigurasi yang telah dimasukkan di sebelah kiri halaman. Ketika data sudah masuk, nama file datalogger akan keluar di kolom list (kedua dari kiri halaman). Ketika file datalogger pada list tersebut di pilih, maka akan menampilkan data pada spreadsheet di sebelah kanan halaman.

Pemakaian daya untuk sistem monitoring LTMS akhirnya dapat dihitung berdasarkan data dari datalogger, yaitu dengan persamaan (1).

$$
P_{\text {monitoring }}=\frac{\sum_{i=1}^{n} P_{\text {input }}-P_{\text {output }}}{n}(1)
$$

\section{HASIL DAN PEMBAHASAN}

PJU bertenaga surya telah diuji selama satu hari tepatnya pada jam 07:20 hari sabtu 29 juli 2020 hingga 07:20 di hari berikutnya. Parameterparameter yang terkirim melalui PLCC termonitor pada pemrograman LabVIEW secara real time dan tercatat pada Datalogger selama 24 jam.

Data yang diambil dalam pengujian ini adalah 16 parameter yang diambil dari masingmasing SCC di PJU1 dan PJU2 dengan sampling time 60 detik (1 menit). Data akan disajikan terpisah, yaitu data PJU1 dan PJU 2 tentang tegangan, arus dan daya dari Photovoltaic (PV) ke SCC, SCC ke baterai dan baterai ke load. Total didapatkan 1357 data selama 24 jam.

Dari parameter-parameter tersebut, dikelompokkan parameter teserbut berdasarkan arah arus listrik, temperature dan kapasitas baterai untuk masing-masing PJU.

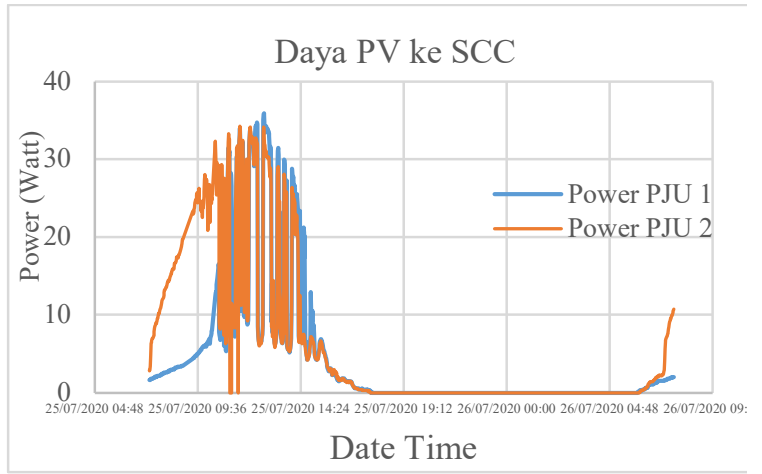

Gambar 9. Daya input PV ke SCC

Pada gambar 9 dapat dijelaskan bahwa daya tertinggi untuk PJU 1 terjadi di tanggal 25 juli
2020 pukul 12:41 dengan nilai 35,92Watt dan untuk PJU 2 terjadi di tanggal 25 juli 2020 pukul 12:40 dengan nilai 34,11Watt. Awal pengisian PJU 1 di tanggal 26 Juli 2020 adalah pukul 06:07 dan PJU 2 06:12. Waktu penerimaan energi oleh PV di PJU 1 dimulai dari pukul 06:07 dan berakhir pada pukul 17:42. Sedangkan di PJU 2 dimulai dari pukul 06:12 dan berakhir pada pukul 17:38.

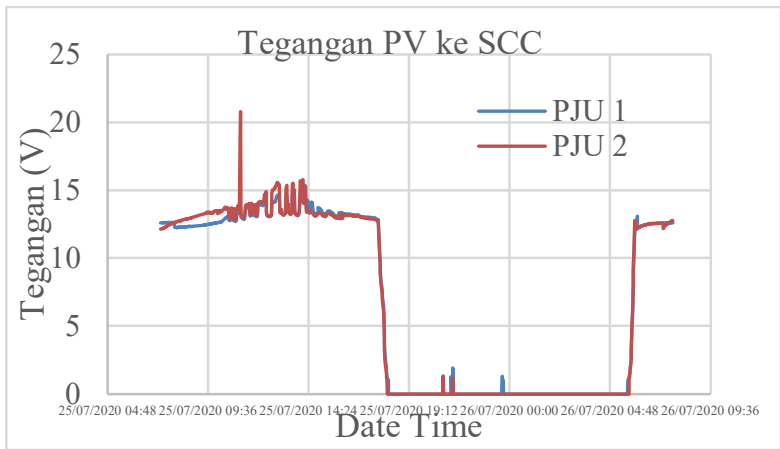

Gambar 10. Tegangan Input PV ke SCC

Penjelasan detail pada gambar 10 adalah, tegangan tertinggi pada PJU 1 juga terjadi pada pukul 12:41 siang, yaitu pada $14,14 \mathrm{~V}$. pada PJU 2 terjadi spike tegangan pada pukul 11:14 yang menyebabkan pembacaan tegangan adalah $20.86 \mathrm{~V}$, hal ini merupakan gangguan pada pembacaan sistem PV oleh SCC. Sedangkan pembacaan tegangan tertinggi pada PJU 2 terjadi pada pukul 12:56 yaitu $15,56 \mathrm{~V}$.

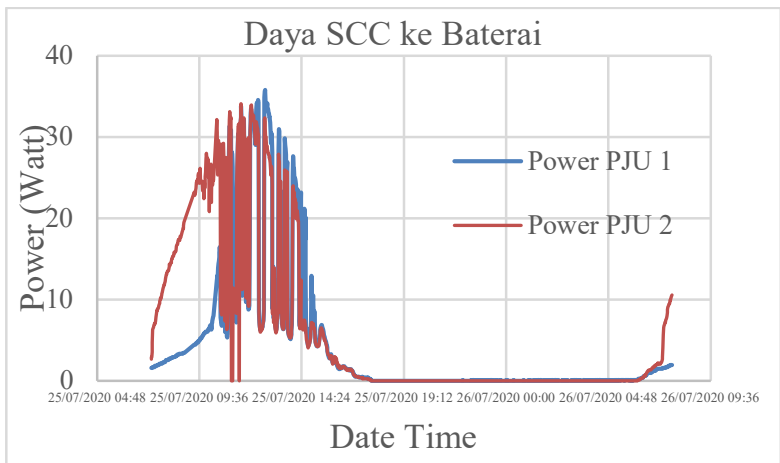

Gambar 11. Daya output SCC ke Baterai

Pada gambar 11 ada perbedaan daya dari SCC ke Baterai dengan PV ke SCC, hal tersebut dikarenakan oleh pemakaian daya yang diperoleh dari PV selain dipakai untuk pengisian baterai juga dipakai untuk mensuplai LTMS dalam panel. Selain itu kenaikan temperature dalam panel menyebabkan bertambah tingginya pemakaian daya oleh LTMS. 


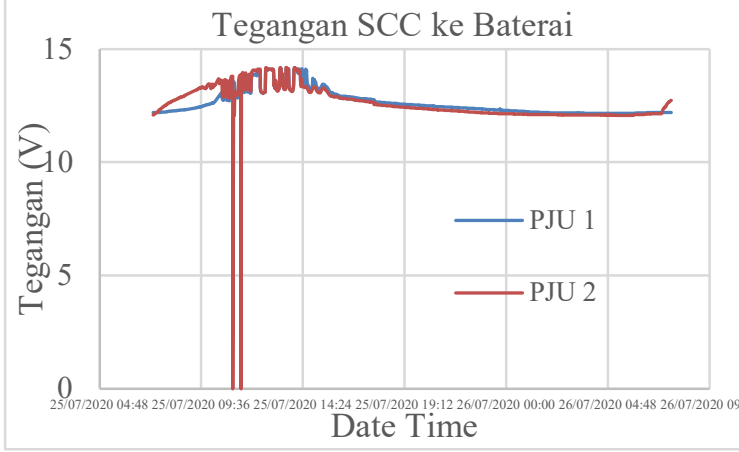

Gambar 12. Tegangan Output SCC ke Baterai

Pada gambar 12 terlihat nilai tertinggi pada PJU 1 dan 2 terjadi pada pukul 14:00 yaitu 14,17V untuk PJU 1 dan 14,19V untuk PJU2. Pada gambar tersebut juga terlihat kehilangan data selama 1 menit yaitu pada pukul 11:05 yang mengakibatkan pembacaan data $0 \mathrm{~V}$, hal ini disebabkan masalah kegagalan pengiriman data oleh PLCC.

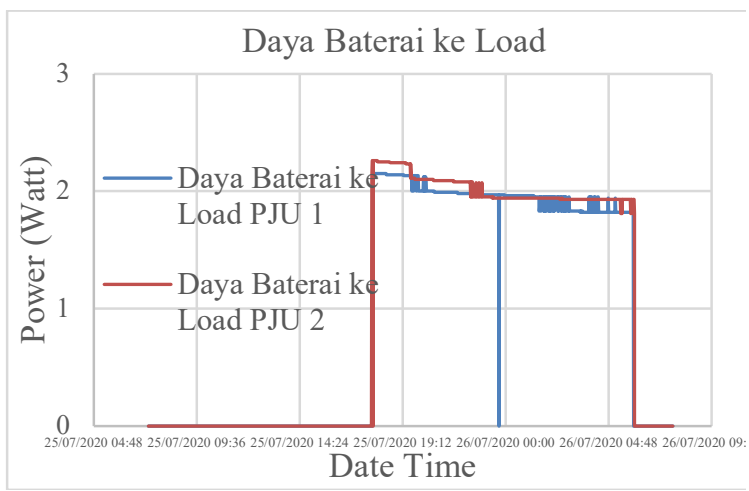

Gambar 13. Daya pemakaian baterai ke load

Pada gambar 13, sensor LDR menangkap kondisi malam hari pada nilai LDR lebih besar dari 700 (range ADC 0-1023). Pada penelitian ini nilai lebih besar dari 700 terjadi pada pukul 17:48 untuk PJU 1 dan 17:46 untuk PJU 2. Sedangkan PV berhenti mendapatkan energi dari matahari pada pukul 17:39 pada PJU 1 dan 2. Bila sensor LDR kurang dari 700 maka menangkap kondisi pagi hari dan PJU mati di pukul 06:07 untuk PJU 1 dan 06:12 untuk PJU 2. Terjadinya penurunan daya pada gambar diatas sebesar 0,32 Watt pada PJU 1 dan 0,33Watt pada PJU 2 disebabkan oleh karakteristik dari PWM SCC itu sendiri.

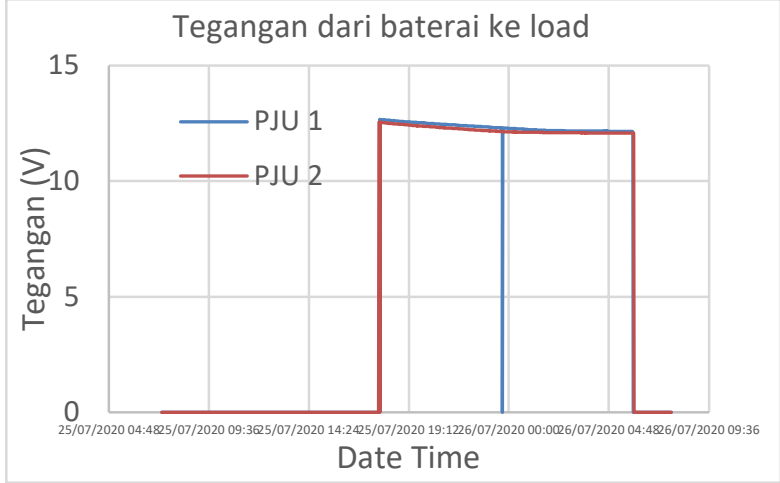

Gambar 14. Tegangan Baterai ke Load

Dapat dilihat pada gambar 14 bahwa grafik tegangan pemakaian lampu dengan daya pemakaian lampu pada gambar 4.5 memiliki grafik yang serupa, tegangan $12,68 \mathrm{~V}$ terpakai pada pukul 17:48 untuk PJU 1 dan 12,55V untuk PJU 2 pada pukul 17:55. Terjadi kehilangan data selama 1 menit di pukul 23:42 pada PJU 1 yang disebabkan oleh kesalahan pengiriman internal oleh Arduino.

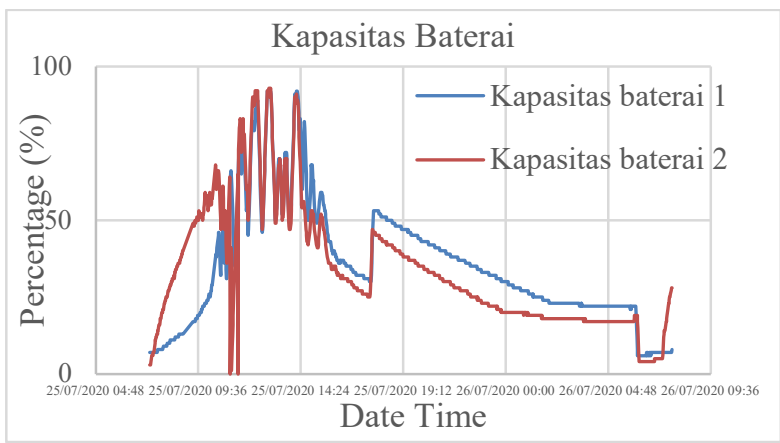

Gambar 15. Pengisian Baterai

Gambar 15 adalah hasil pembacaan kapasitas baterai selama pengisian dan pelepasan (charge and discharge). Kapasitas terendah baterai pada PJU 1 adalah 7\% dengan hasil pengisian oleh PV tertinggi adalah $92 \%$ pada pukul 12:51, sedangkan kapasitas terendah baterai pada PJU 2 adalah 3\% di pagi hari dengan hasil pengisian oleh PV tertinggi adalah 93\% pada pukul 12:55. Terjadi perbedaan pembacaan kapasitas baterai oleh SCC. Perubahan ini terjadi pada pukul 17:40 untuk PJU 1 dari kapasitas 30\% ke $50 \%$ and 17:38 untuk PJU 2 dari kapasitas $25 \%$ ke $47 \%$.

Dari data-data yang telah didapatkan pada penelitian ini maka dapat dilakukan analisis:

- Waktu pengisian baterai untuk PJU bertenaga surya pada penelitian ini di tanggal 25 juli 2020 (musim kemarau) adalah sekitar pukul 06:00 dan berakhir pukul 18:00 dan pengisian tertinggi adalah pada tengah hari sekitar pukul 12:00. 
- Dari persamaan 1, jumlah data terukur adalah 669 data yang berarti daya input dari PV dan daya output SCC ke baterai hanya didapatkan pada pengisian (pagi sampai sore hari). Dengan data daya input dari PV dan daya output SCC ke baterai didapatkan daya rata-rata adalah 0.1 Watt.

- Terjadi perbedaan pengukuran kapasitas baterai di gambar 15. Hal ini disebabkan metode pengukuran SOC (State Of Charge) oleh SCC. Metode yang digunakan oleh alat ini adalah perubahan tingkat tegangan. Ketika PJU tidak menyala disiang hari, SCC mendeteksi SOC dari parameter Charging Equipment Input Voltage dan Current dan Ketika PJU menyala dimalam hari, SCC mendeteksi SOC dari parameter Discharging Equipment Output Voltage dan Current. Hal inilah yang menyebabkan perbedaan pembacaan SOC.

- Daya tertinggi yang dihasilkan PV saat peak adalah 35.9Watt pada pukul 12:41, sedangkan spesifikasi PV 50Watt Peak. Didapatkan efisiensi dari PV yang dipakai adalah 71,84\%.

\section{KESIMPULAN}

1. Rancang bangun LTMS PJU bertenaga surya berbasis PLCC dapat menggantikan/mengupgrade PJU bertenaga surya konvensional.

2. PLCC dengan protocol modbus TCP berhasil menjadi komunikasi antara sistem monitoring PJU dengan kontrol utama

3. Pemakaian daya LTMS rata-rata adalah 0.1 Watt

4. Daya tertinggi yang dihasilkan PV saat peak adalah 35.92Watt pada pukul 12:41, sedangkan spesifikasi PV 50Watt Peak. Didapatkan efisiensi dari PV yang dipakai adalah $71,84 \%$.

\section{DAFTAR PUSTAKA}

[1] A. M. Ardianto. 2017. Rancang Bangun Prototype Penerangan Jalan Umum Cerdas dan Efektif. Politeknik Negeri Sriwijaya, Palembang

[2] R. V. Clark. 2008. Improving Street Lighting to Reduce Crime in Residential Area. U.S. Department of Justice, San Diego

[3] Anon. 2018. Peraturan Menteri Perhubungan Republik Indonesia Nomor
27 Tahun 2018 Tentang Alat Penerangan Jalan. Menteri Perhubungan Republik Indonesia, Jakarta

[4] U. M. Ardiaksa. 2016. PLCC (Power Line Carrier Communication). Politeknik Elektronika Negeri Surabaya, Surabaya

[5] R. Sianipar. 2014. Dasar Perencanaan Pembangkit Listrik Tenaga Surya. JETri, vol. 11 , no. 2 , pp. $61-78$

[6] S. B. Julianto. 2013. Pengaruh Suhu Terhadap Hambatan Rangkaian Listrik. Jurnal Fisika Unnes, vol. 3 